\title{
THE SPEECH ACTS OF SELLERS AND BUYERS IN THE GELUMBANG VILLAGE MARKET, GELUMBANG DISTRICT, MUARA ENIM REGENCY
}

\author{
Rusni $^{1)}$ \\ 1) Pascasarjana Universitas PGRI Palembang, Palembang, Indonesia \\ E-mail: asanirusni@gmail.com
}

\begin{abstract}
This study aims to describe the speech acts of sellers and buyers in the Gelumbang Village Market, Gelumbang District, Muara Enim Regency. The method used in this research is the content analysis method. The data source used is a conversation between sellers and buyers in the Gelumbang Village Market, Gelumbang District, Muara Enim Regency. The results obtained from this study are the speech acts that are dominantly used are representative speech acts and the least speech acts used are declarative speech acts. The reason for representative speech acts is more dominant to be used because these speech acts contain a lot of information as well as the submission of something in a buying and selling transaction (bargaining). Based on this research the research results can also be obtained that female sellers and buyers have higher speech levels than those of male sellers and buyers. This has become a characteristic or characteristic of women that is more active and clever in speaking, especially in buying and selling activities that include demand for goods and price quotes for goods in the Gelumbang Village Market, Gelumbang District, Muara Enim Regency than men.
\end{abstract}

Key word: Speech Act, Gelumbang Village Market, Seller and Buyer

\section{PRELIMINARY}

Speech act is a speech from someone who is psychological and seen from the meaning of the action of the speech. speech action is included in an action because in speaking every individual can do something according to his purpose in speaking. when speaking we sometimes give advice to opponents talk, promise, invite, ask, and forbid them to do things as they wish. all of these intentions can be achieved if in speaking, using the right strategy such as the use of language that is straightforward, clear, and precise so that the other person provides clear information or information about himself (Sumarsono, 2014: 322).

Speech event is the occurrence or continuation of linguistic interaction in one or more forms of utterance involving two parties, namely the speaker and the interlocutor (Chaer et al, 2002: 47). Thus the speech act occurs between two or more parties who interact in a conversation event in a condition or place. On the other hand, according to Ibrahim (1993: 109), speech acts include psychological, social situations outside the discourse that occur or make contracts that occur and have long-term consequences. In other words the speech act has the consequence that what is said will be a long-term impact on the speaker and the interlocutor in an event.

Lasmono et al. (2013: 3) suggest that pragmatically there are at least three types of actions that can be realized by a speaker, namely the act of locus speech (lucutionary act), illocutionary act (ilocutionary act), and act of perlocution (perlocutionary act). The speech act expressed in a place has the purpose and function of each, as well as the meaning and purpose which will be different from what is said and implied in the conversation.

Geminastiti and Nella (2016: 123) define the market as a place for buying and selling goods and services to meet the needs of the community. Markets can be found in various places and conditions. In a narrow sense, the market is a meeting place for sellers and buyers to enter into sale and purchase transactions of goods and services. However, along with the times, transactions can be done without directly bringing together sellers and buyers. This has led to the understanding of the market in a broad sense, namely the process of interaction between sellers and buyers to reach market prices. 
The market is classified into two, namely: traditional markets and modern markets. In this case, the researcher will examine the speech acts on the sale and purchase interactions in the Gelumbang Village Market, which is a traditional market located in the Gelumbang District of Muara Enim Regency. In this market many sell various community needs, both primary and secondary needs. In this market the intensity of sales is also very crowded, so speech acts are a daily sight that occurs in this Gelumbang market.

According to Sinta (2018: 3), speech acts are part of pragmatics, and pragmatics itself is part of linguistic performance. In addition to speech acts, in a conversation generally conducted by two participants who have two functions, namely as a speaker and listener. Therefore, it can be said in a conversation the two participants are called pairs side by side or in accordance. A conversation can be known for clarity or can be understood if the reader knows the context of the conversation situation because the meaning of the word or the meaning of a sentence is related to the context.

Conversations conducted by the seller and seller in the market In the form of utterances or speech acts vary with the specific purpose and objectives of each person. Thus, it can be said that what is said or utterances from buyers and sellers in the market not only produces words but also shows what actions are implied in these utterances. The speech also expresses the emotions of each buyer and seller in terms of language. From the speeches spoken by the speakers, the listener can know their intentions and emotions: like when they are angry, happy, bossing, rejecting, asking, apologizing, complaining, and much more. All of these intentions and emotions can be realized in the form of sentences (question sentences, command sentences, statement sentences), clauses and phrases. Such utterances are called speech acts.

This was stated by Yule (1996: 47) that speech acts are actions performed via utterances. The meaning of that understanding is that when someone says something he not only produces words that have meaning but also shows an action. The sentence "Do you have time tonight?", For example, not only means a question sentence asking if the speaker is busy that night (request of information) but the speaker might intend to invite the speaker that night. Inviting is the act of the speaker who is actually reflected in the sentence he utters. A speaker's speech can contain different purposes depending on the context that accompanies it. If the speaker can recognize the intention of the speaker's actions, the conversation between the two parties can proceed well. Because, sometimes someone does not say their intentions explicitly so that the speaker must be able to capture the implicit meaning of the speaker so that misunderstanding does not occur. Just as is the case in the market, when buyers ask prices or bargain prices of goods available to the buyer, it happens that sometimes when the buyer bids the price too low then sometimes the seller responds with soft words that mean very rude. But on the other hand, the intention of the speaker is only to see whether the offer price is in accordance with what is meant.

Based on the description above, this study focuses on three types of speech acts and their forms, both directly and indirectly, literal and indirect, which will limit the subject matter to be discussed. This study intends to find out the speech acts used by sellers and buyers in the Gelumbang Village Market, Gelumbang District, Muara Enim Regency.

\section{RESEARCH METHODS}

Sugiyono (2017: 11) said that in general the research method was defined as a scientific way to obtain data with specific purposes and uses. This research uses descriptive method which aims to describe the situation clearly, in detail, systematically and then put forward in words or sentences. Arikunto (2010: 74) defines that research is descriptive, that is, explaining or explaining events.

The author uses descriptive methods in this study in order to be able to narrate various kinds of speech acts, namely locution, illocution, and perlocution as well as direct and indirect speech types as well as from the literal and non-literal standpoints contained in the acts of sellers and buyers in the Gelumbang District Market Gelumbang Muara Enim Regency.

Data sources in this study consisted of sellers and buyers in the Gelumbang Market, Gelumbang Village, Gelumbang District, Muara Enim Regency. Data in the form of language use or dialogue or speech is obtained from the seller of chickens, fruits, vegetables, nine staples and household appliances. The trader or seller is sampled by more than one trader so that the data obtained is more complete, detailed and detailed. As for the type of data processed in the form of oral data from the speaker (buyer) and the speech partner (seller) which contains illocutionary speech acts consisting of assertive, directive, expressive, commissive and declarative speech.

According to Sugiyono (2015: 244), argued that data analysis is the process of systematically searching and compiling data obtained from interviews, field notes, or documentation. Data analysis in this study used content analysis techniques with procedures, namely (1) Changing recorded data into written text that is data recorded on mobile phones transferred into written text, (2) Identifying conversations that were conversations by sellers and buyers in the Gelumbang Village Market (3) Classifying conversations that occur during speech that contains speech acts into texts according to the recording date, (4) Clarifying conversations that occur by sellers and buyers in the Gelumbang Village Market and (4) Making conclusions.

\section{RESEARCH RESULTS AND DISCUSSION}


Based on the research results, it can be seen that there are five types of speech acts used by buyers and sellers (chicken, household items, vegetables, basic food and watermelon) in Gelumbang Market, Gelumbang Village, Gelumbang District, Muara Enim Regency. The five types of illocutionary speech acts are (1) representative speech acts, (2) directive speech acts, (3) expressive speech acts, (4) commissive speech acts and (5) declarative speech acts.

Representative speech acts are the most common speech acts and are often used in conversation interactions between buyers and sellers as speakers and speech partners. According to Searle (quoted by Tarigan, 1990: 47-48), representative speech acts contain speech that binds the speaker of the truth of what is being said, for example stating, proposing, boasting, complaining, expressing opinions, reporting. Based on data that has been obtained and processed, the number of representative speech acts in conversations between sellers and buyers is 51 speeches. 51 utterances consist of 11 utterances from chicken buyers and sellers (PA), 10 utterances from household appliance buyers and sellers (PART), 9 utterances from vegetable buyers and sellers (PS), 11 utterances from grocery buyers and sellers (PSem) and 10 utterances from buyers and sellers of watermelon (PBS).

The second speech act, which is used by the buyer and seller is the directive speech act. The directive speech act is the speech act that aims to make the speech partner do what the speaker says. This was stated by Searle (Tarigan quoted, 1990: 47-48) that directive speech acts are speech acts intended by the speaker to make the listener perform the actions mentioned in the speech, such as prohibition, rule, request, demand, give advice). Based on data that has been obtained and processed, the number of directive speech acts in conversations between sellers and buyers is 18 utterances. 18 utterances consist of 2 utterances from chicken buyers and sellers (PA), 4 utterances from buyers and sellers of household appliances (PART), 3 utterances from vegetable buyers and sellers (PS), 4 utterances from buyers and sellers of groceries (PSem) and 5 utterances from buyers and sellers of watermelon (PBS). The most commonly used utterances are the governing utterances found in utterances between buyers and sellers of watermelon (PBS).

The third speech act is expressive speech act. Expressive speech acts are speech acts that describe the psychological or psychological attitude of the speaker verbally in the process of buying and selling transactions. This is in line with what was expressed by Searle (Tarigan quoted, 1990: 47-48), that expressive speech acts are illocutionary functions to express the psychological attitude of the speaker towards the state implicit in the illocution, such as saying thank you, congratulating, forgiving, threaten, praise, offer condolences. With the above understanding, it can be said that expressive speech acts are related to the response given by the speaker to something that other people do or feel. Based on data that has been obtained from a dialogue between sellers and buyers in the Gelumbang Market, Gelumbang Village, the number of expressive speech acts is 8 utterances. 8 utterances consist of 2 utterances from chicken buyers and sellers (PA), 1 utterance from buyers and sellers of household appliances (PART), 2 utterances from vegetable buyers and sellers (PS), 2 utterances from buyers and sellers of groceries (PSem) and 1 speech from the buyer and seller of watermelon (PBS). The most commonly used utterances are the gratitude found in the speech between the buyer and seller of chicken, the seller of household appliances (PART) and the seller of groceries (PSem).

The fourth speech act is commissive speech act. Commissive speech acts are speech acts that are bound to an action to be taken, or are the plan of the speaker. Searle (quoted by Tarigan, 1990: 47-48) revealed that the illocution in which the speaker is bound to an action in the future, for example promising, offering, vows / vows. Based on data that has been obtained from a dialogue between sellers and buyers in the Gelumbang Market, Gelumbang Village, the number of commissive speech acts is 11 utterances. 11 utterances consist of 3 utterances from chicken buyers and sellers (PA), 2 utterances from buyers and sellers of household appliances (PART), 3 utterances from vegetable buyers and sellers (PS) and 1 utterance from staple buyers and sellers (PSem) and 2 utterances from buyers and sellers of watermelon (PBS). The most commonly used utterances are offerings which are contained in speech between the buyer and seller of chicken (PA). Some things that are offered in the dialogue between the seller and the buyer are the product offer and the price offer.

The last speech act is a declarative speech act. Declarative speech acts are the least and rarely used speech acts by buyers and sellers in the Gelumbang Market, Gelumbang District. This declarative speech act is a speech act which results in conformity between the contents of the proposition and reality. For example, resigning, baptizing, firing, giving names, sentencing, isolating, demanding. That understanding was put forward by Searle (quoted by Tarigan, 1990: 47-48). The use of speech acts only amounts to 5 utterances. 5 utterances consist of 1 utterance from the buyer and seller of chicken (PA), 1 utterance from the buyer and seller of household appliances (PART), 1 utterance from the buyer and seller of vegetables (PS), 1 utterance from the buyer and seller of groceries (PSem) and 1 speech from the buyer and seller of watermelon (PBS). There is no speech act that is most widely used is in resignation.

Basically all of the speech acts above are used in interactions between the speaker and the speech partner, but the capacity of using representative speech acts is greater than the other four speech acts. Buyers are much more active in asking, proposing and stating something in the form of prices or prices of goods to be purchased, this is the reason why representative speech acts are more 
dominantly used in the buying and selling process in the Gelumbang Market, Gelumbang Village. The percentage of representative speech acts was $55.43 \%$ and became the highest percentage. The percentage of directive speech acts was $19.56 \%$, the percentage of expressive speech acts was $8.67 \%$ commissive speech acts by $11.95 \%$ and the lowest speech acts were declarative speech acts by $5.43 \%$.

The dominant speech act used is representative speech act, namely speech that functions to express or state something. In this case it relates to the items that the buyer wants to buy contained in the speech of the buyer and seller of chicken (PA) and groceries seller (PSem).

The following is a percentage of speech act usage used in the Gelumbang Market.

Table 4.1

Percentage of Speech Actions Used in the Gelumbang Market, Gelumbang Village

\begin{tabular}{|c|c|c|c|}
\hline No & $\begin{array}{c}\text { Types of Speech } \\
\text { Acts }\end{array}$ & Amount & Percentage \\
\hline 1. & $\begin{array}{c}\text { Representative } \\
\text { Speech Act }\end{array}$ & 51 & $55,43 \%$ \\
\hline 2. & $\begin{array}{c}\text { Direktive Speech } \\
\text { Act }\end{array}$ & 18 & $19,56 \%$ \\
\hline 3. & $\begin{array}{c}\text { Ekspresive Speech } \\
\text { Act }\end{array}$ & 8 & $8,69 \%$ \\
\hline 4. & $\begin{array}{c}\text { Komisive Speech Act } \\
\text { Act }\end{array}$ & 11 & $11,95 \%$ \\
\hline 5. & $\begin{array}{c}\text { Deklarative Speech } \\
\text { Act }\end{array}$ & 5 & $5,43 \%$ \\
\hline
\end{tabular}

Based on these data, it can be concluded that the representative speech acts are more dominantly used in the speech acts of sellers and buyers in the Gelumbang Village Market, Muara Enim Regency which is as much as $55.43 \%$.

\section{Implications of Research Conducted on Indonesian Language Learning in Schools}

The study, entitled The Speech Acts of Sellers and Buyers in the Gelumbang Village Market, Gelumbang District, Muara Enim Regency has implications for learning Indonesian in schools. Based on the 2013 curriculum for high school class X Indonesian subjects, there is a KD 3.10 about Explaining Submissions, Offers and Approval in Negotiating Texts.

The research that has been carried out includes a dialogue of the sale and purchase transaction which contains the submission of goods and prices of goods, price quotes and purchase agreements for goods in the form of chicken, household goods, groceries, vegetables and watermelons, so that this study can be an example of teaching materials used by teachers in teaching activities in class X especially about negotiating text material. Besides KD 3.10, there is KD 4.2 about Developing procedure texts by paying attention to the results of the analysis of the contents, structure, and language. In the study, there were directive speech acts related to commanding actions and forbidding speech partners to do anything. This research is inseparable from the command and prohibition sentences. Procedure text is text that contains steps in doing something, which contains command sentences and even sentences that state restrictions. Based on this, this study can also be used as teaching material in giving examples of command and prohibition sentences in the text of procedure texts in class XI of high school.

\section{CLOSING}

\section{Conclusion}

Based on data analysis of the speech acts of buyers and sellers in the Gelumbang Market, Gelumbang Village, Gelumbang District, it can be concluded that the dominant speech acts used are representative speech acts and the least used speech acts are declarative speech acts.

The reason for representative speech acts is more dominantly used in the Gelumbang Market, Gelumbang Urban Village, because these speech acts contain a lot of dialogue about buying and selling transactions (bargaining) in the form of submission and purchase of information about the goods as well as the price of the goods to be purchased. Basically all of the illocutionary speech acts above are used in interactions between the speaker and the speech partner, but the capacity of using representative speech acts is greater than the other four speech acts.

Buyers are much more active in asking, proposing and stating something in the form of prices or prices of goods to be purchased, this is the reason why representative speech acts are more dominantly used in the buying and selling process in the Gelumbang Market, Gelumbang Village.

Based on this research the research results can also be obtained that female sellers and buyers have higher speech levels than those of male sellers and buyers. This has become a characteristic or characteristic of women, namely being more active and clever in speaking, especially in buying and selling activities that include demand for goods and price quotes for goods in the Gelumbang Village Market, Gelumbang District, Muara Enim Regency than men. The statement can be proven through the number of female sellers' utterances as many as 24 female and female 
buyers as many as 39 while male female sellers speak only 15 and male as many as 21 female buyers.

\section{Suggestion}

This study discusses the acts of sellers and buyers in the Gelumbang Village Market, Gelumbang District, Muara Enim Regency. Other researchers can examine the characteristics or characteristics between sellers and buyers in other traditional markets as further research of the research that has been done by researchers.

\section{BIBLIOGRAPHY}

[1] Arikunto, Suharsimi. 2010. Prosedur Penelitian Suatu Pendekatan Praktik. Jakarta: Rineka Cipta.

[2] Chaer, Abdul dan Leonie Agustina. 2010. Sosiolinguistik Perkenalan Awal. Jakarta: Rineka Cipta.

[3] Geminastiti, Kinanti dan Nella Nurlita. 2016. Ekonomi untuk Siswa SMA/MA Kelas X: Kelompok Peminatan Ilmu-ilmu Sosial. Bandung. Yrama Widya.

[4] Ibrahim, Syukur Abdul. 1993. Kajian Tindak Tutur. Surabaya: Usaha Nasional.

[5] Kemendikbud RI. 2017. Bahasa Indonesia untuk SMA/SMK/MA Kelas X. Jakarta: Pusat Kurikulum dan Perbukuan, Balitbang.

[6] Sinta, Suci Rahma. 2018. Tindak Tutur Ilokusi pada Interaksi Jual Beli di Pasar Tradisional Bengkel dalam Bahasa Jawa Kajian Pragmatik. Tesis Universitas Sumatera Utara.

[7] Sugiyono. 2013. Metode Penelitian Pendidikan Pendekatan Kuantitatif, Kualitatif, dan R\&D. Bandung: Alfabeta.

[8] Sumarsono. 2014. Sosiolinguistik. Yogyakarta: Pustaka Pelajar.

[9] Tarigan, Hendry Guntur. 2009. Pengajaran Pragmatik. Bandung: Angkasa.

[10] Yule, George. 2006. Pragmatik. Yogyakarta: Pustaka Belajar. 